\title{
Predictors of Urinary Infections and Urosepsis After Ureteroscopy for Stone Disease: a Systematic Review from EAU Section of Urolithiasis (EULIS)
}

\author{
Shreya Chugh ${ }^{1} \cdot$ Amelia Pietropaolo $^{1} \cdot$ Emanuele Montanari $^{2} \cdot$ Kemal Sarica $^{3} \cdot$ Bhaskar K. Somani $^{1}$
}

Published online: 24 March 2020

(C) The Author(s) 2020

\begin{abstract}
Purpose of Review To present the latest evidence related to the predictors of urinary tract infections (UTIs) and urosepsis after ureteroscopy (URS) for stone disease.

Recent Findings Our review suggests that almost half of all post-URS complications are related to infectious complications although reported rates of urosepsis were low. The use of antibiotic prophylaxis, treatment of pre-operative UTI, and low procedural time seem to reduce this risk. However, the risk is higher in patients with higher Charlson comorbidity index, elderly patients, female gender, long duration of pre-procedural indwelling ureteric stents and patients with a neurogenic bladder and with high BMI.

Summary Infectious complications following ureteroscopy can be a source of morbidity and potential mortality. Although majority of these are minor, efforts must be taken to minimise them especially in high-risk patients. This includes the use of prophylactic antibiotics, limiting stent dwell and procedural time, prompt identification and treatment of UTI and urosepsis, and careful planning in patients with large stone burden and multiple comorbidities.
\end{abstract}

Keywords Ureteroscopy · Sepsis · Urosepsis · UTI · Complication · Stent · Urine culture · Antibiotic $\cdot$ Access sheath

This article is part of the Topical Collection on Endourology

Bhaskar K. Somani

bhaskarsomani@yahoo.com

Shreya Chugh

shreya_chugh@hotmail.co.uk

Amelia Pietropaolo

Pietropaolo@uhs.nhs.uk

Emanuele Montanari

montanari.emanuele@gmail.com

Kemal Sarica

saricakemal@gmail.com

1 University Hospital Southampton NHS Trust, Southampton, UK

2 Department of Urology, Fondazione Ca'Granda Ospedale Maggiore Policlinico di Milano, Università degli Studi di Milano, Milan, Italy

3 Department of Urology, Biruni University Medical School, Istanbul, Turkey

\section{Introduction}

The prevalence and incidence of kidney stone disease (KSD) have been increasing globally in the last 50 years [1]. In England, national data from 2006/2007 to 2013/2014 shows that there has been an increase in the lifetime prevalence of urolithiasis-based admissions and intervention from the historically reported 10 to $14 \%$ [2]. This is due to a rise in metabolic syndrome, lifestyle changes but also partly due to global warming as higher monthly ambient temperatures are positively associated with incidence of kidney stones [3•]. Treatment options include ureteroscopy (URS), shock wave lithotripsy (SWL) and percutaneous nephrolithotomy (PCNL) [4-6].

Published data from the last 15-20 years has shown a steep rise in the use of URS and PCNL, while the use of SWL and open surgery have declined $[7 \bullet, 8]$. Moreover, URS has shown to achieve higher stone-free rates than SWL and lower complication rates compared with PCNL $[4,5]$.

Following URS, the overall rate of complications varies between 9 and $25 \%$ although the majority of these are minor and does not require intervention [9-11]. Infectious complications ranging from fever, systemic inflammatory response 
syndrome to urinary tract infection (both upper and lower) are some of the more common post-ureteroscopy complications, alongside haematuria and post-operative pain [11], with overall complication rates of up to $25 \%[12,13 \bullet]$. As ureteroscopy is being performed in increasing numbers with the rising prevalence of KSD [2], it is to be expected that the rate of infectious post-URS complications is consequently also increasing $[13,14]$. Similarly, the indications of ureteroscopy have expanded, and it is now being performed for high-risk patients such as solitary kidneys, paediatrics, pregnancy and upper tract tumours [15-17].

In the literature, there are many small, medium and highvolume prospective studies that have reported on the infectious complications following URS for renal stone disease [18-29]. Some studies have also looked at the risk factors for urinary infections following ureteroscopy and advised on strategies to reduce these risks. However, there is a lack of data on the predictors of post-ureteroscopy infectious complications. We conducted a systematic review of literature looking at the infection-related post-ureteroscopy complications reported from high-volume centres.

\section{Materials and Methods}

\section{Search Strategy and Study Selection}

The systematic review was performed according to the Cochrane review guidelines and in accordance with the Preferred Reporting Items for Systematic Reviews and Meta-analyses (PRISMA) checklist from January 2009 to November 2019 for English language articles $[30,31]$. The search strategy was conducted to find relevant studies from the Medline, EMBASE, Scopus, Cochrane Library, CINAHL, Clinicaltrials.gov, Google Scholar and individual urologic journals. The search terms included 'ureteroscopy', 'URS', 'complications', 'urosepsis', 'urinary tract infection', 'UTI', 'retrograde intrarenal surgery', 'RIRS', 'systemic inflammatory response syndrome', 'SIRS', 'infection', 'bacteraemia', 'mortality' and 'death'.

A cutoff of 400 patients was set to include studies from high-volume endourological centres with relevant endourological experience. All original studies were included and where more than one article was available, the study with the longest follow-up was included. The review was carried out by two reviewers (SC and BKS) independently, and all discrepancies were resolved with mutual agreement.

\section{Evidence Acquisition}

Inclusion criteria:

1. Studies reporting on infectious complications postureteroscopy

2. Studies from high-volume endourological centres reporting on a minimum of 400 patients

3. Studies in English language

Exclusion criteria:

1. Reviews, commentaries or studies with less than 400 patients

2. Paediatric population

3. Ureteroscopy performed for non-stone disease
Fig. 1 PRISMA flowchart of the included studies

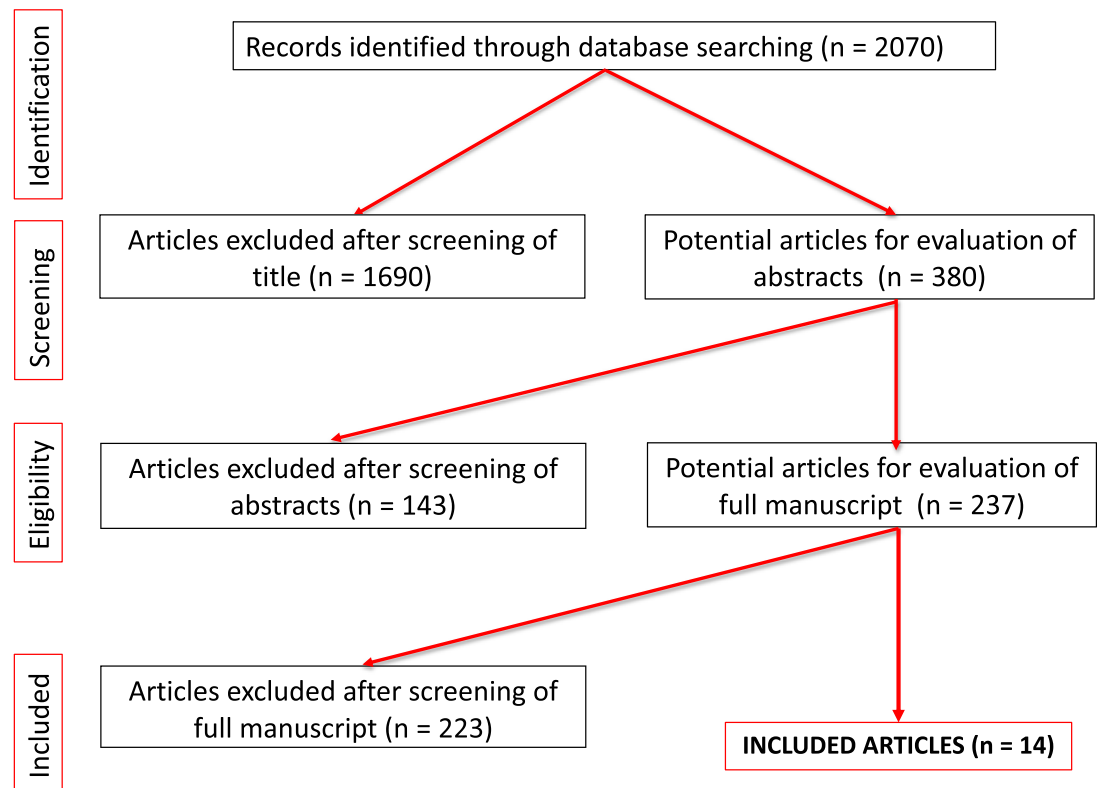







Table 2 Details of infectious and non-infectious complications from the included studies

\begin{tabular}{|c|c|c|c|c|c|c|c|}
\hline Paper & $\begin{array}{l}\text { Number of } \\
\text { procedures }(N)\end{array}$ & $\begin{array}{l}\text { Stone length } \\
(\mathrm{mm}) \text { (range) }\end{array}$ & Stone location & $\begin{array}{l}\text { Ureteral access } \\
\text { sheath utilisation } \\
(n)(\%)\end{array}$ & $\begin{array}{l}\text { Mean operating } \\
\text { time (mins) }\end{array}$ & $\begin{array}{l}\text { Stone- } \\
\text { free } \\
\text { rate }(\%)\end{array}$ & $\begin{array}{l}\text { Non infective } \\
\text { complications } \\
(n)(\%)\end{array}$ \\
\hline $\begin{array}{l}\text { Pricop C, Dorobăt C, } \\
\text { Puia D et al. }\end{array}$ & 473 & Majority 6-8 & Ureteric- $-100 \%$ & $\mathrm{~N} / \mathrm{S}$ & $\mathrm{N} / \mathrm{S}$ & $\mathrm{N} / \mathrm{S}$ & $\mathrm{N} / \mathrm{S}$ \\
\hline $\begin{array}{l}\text { Martov A, Gravas S, } \\
\text { Etemadian M et al. }\end{array}$ & 2650 & $\mathrm{~N} / \mathrm{S}$ & $\begin{array}{l}\text { Ureteric-85.7\%; } \\
\quad \text { renal-13.2\% }\end{array}$ & $\mathrm{N} / \mathrm{S}$ & 51.3 & $90.80 \%$ & $\begin{array}{l}4.75 \% \text { - } \\
\text { intraoperative }\end{array}$ \\
\hline $\begin{array}{l}\text { Özsoy M, Acar Ö, } \\
\text { Sarica K et al. }\end{array}$ & 927 & $\mathrm{~N} / \mathrm{S}$ & $\mathrm{N} / \mathrm{S}$ & $\mathrm{N} / \mathrm{S}$ & 41.4 & $87 \%$ & $15.20 \%$ \\
\hline $\begin{array}{l}\text { Moses RA, Ghali FM, } \\
\text { Pais VM Jr. et al. }\end{array}$ & 550 & $\mathrm{~N} / \mathrm{S}$ & $\mathrm{N} / \mathrm{S}$ & $\mathrm{N} / \mathrm{S}$ & $\mathrm{N} / \mathrm{S}$ & $\mathrm{N} / \mathrm{S}$ & $\mathrm{N} / \mathrm{S}$ \\
\hline $\begin{array}{l}\text { James P. Blackmur, } \\
\text { Neil U. Maitra, } \\
\text { Rajendar R. Marri et al. }\end{array}$ & 462 & $\mathrm{~N} / \mathrm{S}$ & $\begin{array}{l}\text { Ureteric-212 }(45.9 \%) \\
\quad \text { renal-250 }(54.1 \%)\end{array}$ & $240(56 \%)$ & $\begin{array}{l}\text { Majority } \\
30-40 \mathrm{~min}\end{array}$ & $83.40 \%$ & $\mathrm{~N} / \mathrm{S}$ \\
\hline $\begin{array}{l}\text { Dessyn JF, Balssa L, } \\
\text { Chabannes E et al. }\end{array}$ & 497 & 9.3 & $\begin{array}{l}\text { Ureteric-126 }(25.3 \%) \\
\text { renal-398 }(79.7 \%) \\
\text { multiple-118 }(23.7 \%)\end{array}$ & $377(75.9 \%)$ & 96.8 & $68 \%$ & $\mathrm{~N} / \mathrm{S}$ \\
\hline $\begin{array}{l}\text { Berardinelli F, De } \\
\text { Francesco P, Marchioni } \\
\text { M et al. }\end{array}$ & 403 & $12.21 \pm 5.31$ & $\mathrm{~N} / \mathrm{S}$ & $322(79.9 \&)$ & 62.42 & $70.7 \%$ & $\mathrm{~N} / \mathrm{S}$ \\
\hline $\begin{array}{l}\text { Nevo A, Mano R, } \\
\text { Baniel J et al. }\end{array}$ & 1256 & $8(7-12)$ & $\mathrm{N} / \mathrm{S}$ & $239(19 \%)$ & 45 & $\mathrm{~N} / \mathrm{S}$ & $\mathrm{N} / \mathrm{S}$ \\
\hline $\begin{array}{l}\text { Somani BK, Giusti G, } \\
\text { Sun Y et al. }\end{array}$ & 11,885 & $\mathrm{~N} / \mathrm{S}$ & $\begin{array}{l}\text { Ureteric-69.6\%; renal- } \\
\quad 18.1 \% ; \text { mixed-8.9\% }\end{array}$ & $2263(19 \%)$ & 40.7 & $85.8 \%$ & $7.2 \%$ \\
\hline $\begin{array}{l}\text { Ghosh A, Oliver R, } \\
\text { Way C, White L, } \\
\text { Somani BK }\end{array}$ & 544 & $14.3(10.9-34.3)$ & $\begin{array}{l}\text { Multiple-25.9\%; } \\
\text { renal-57.9\%; } \\
\text { ureteric-43.6\%; } \\
\text { lower pole-28.3\% }\end{array}$ & $206(38 \%)$ & 46.6 & $94.2 \%$ & $9(1.65 \%)$ \\
\hline $\begin{array}{l}\text { Stauffer CE, Snyder E, } \\
\text { Ngo TC et al. }\end{array}$ & 467 & 9.2 & $\mathrm{~N} / \mathrm{S}$ & $\mathrm{N} / \mathrm{S}$ & $\mathrm{N} / \mathrm{S}$ & $\mathrm{N} / \mathrm{S}$ & $\mathrm{N} / \mathrm{S}$ \\
\hline $\begin{array}{l}\text { C Senocak, C Ozcan, } \\
\text { T Sahin et al. }\end{array}$ & 492 & $13(10-16)$ & $\begin{array}{l}\text { Ureteric-18.0\%; } \\
\quad \text { renal-81.8\% }\end{array}$ & $458(93.1 \%)$ & 57 & $\mathrm{~N} / \mathrm{S}$ & $61(12.4 \%)$ \\
\hline $\begin{array}{l}\text { Uchida Y, Takazawa R, } \\
\text { Kitayama S et al. }\end{array}$ & 469 & $10(3-47)$ & $\begin{array}{l}\text { Renal-77 }(16.4 \%) \\
\text { ureteric-392 } \\
\quad(83.5 \%)\end{array}$ & $\mathrm{N} / \mathrm{S}$ & 64 & 84.4 & $\mathrm{~N} / \mathrm{S}$ \\
\hline $\begin{array}{l}\text { Southern JB, Higgins } \\
\text { AM, Young AJ et al. }\end{array}$ & 3298 & $\mathrm{~N} / \mathrm{S}$ & $\begin{array}{l}\text { Ureteral-32.7\%; } \\
\text { renal-43.4\%; } \\
\text { both-23.9\% }\end{array}$ & $2183(66.2 \%)$ & 49 & $\mathrm{~N} / \mathrm{S}$ & $\mathrm{N} / \mathrm{S}$ \\
\hline
\end{tabular}

\begin{tabular}{|c|c|c|c|c|c|c|c|c|}
\hline \multirow[t]{2}{*}{ Paper } & \multirow{2}{*}{$\begin{array}{l}\text { Stone- } \\
\text { free } \\
\text { rate }(\%)\end{array}$} & \multicolumn{5}{|c|}{ Infectious complications $(n)(\%)$} & \multirow{2}{*}{$\begin{array}{l}\text { Total } \\
\text { complications } \\
(n)(\% \text { of } N)\end{array}$} & \multirow{2}{*}{$\begin{array}{l}\text { Overall grade of complications } \\
(n)(\% \text { of } n)\end{array}$} \\
\hline & & Fever & SIRS & UTI & Sepsis & Total & & \\
\hline $\begin{array}{l}\text { Pricop C, Dorobăt C, } \\
\text { Puia D et al. }\end{array}$ & $\mathrm{N} / \mathrm{S}$ & $108(22.8 \%)$ & $\mathrm{N} / \mathrm{S}$ & $\mathrm{N} / \mathrm{S}$ & $\mathrm{N} / \mathrm{S}$ & $108(22.8 \%)$ & $108(22.8 \%)$ & Grade I-108 (22.8\%) \\
\hline $\begin{array}{l}\text { Martov A, Gravas S, } \\
\text { Etemadian M et al. }\end{array}$ & $90.80 \%$ & $27(1.0 \%)$ & $\mathrm{N} / \mathrm{S}$ & $17(0.64 \%)$ & $\mathrm{N} / \mathrm{S}$ & $44(1.66 \%)$ & $170(6.41 \%)$ & $\begin{array}{l}\text { Grade I-26 }(1.58 \%) \text {; grade II—-16 } \\
\quad(0.6 \%) \text {; grade IIIa-6 }(0.23 \%) ; \\
\text { grade IIIb-7 }(0.26 \%) \text {; grade } \\
\text { IVa-4 }(0.11 \%) ; \text { grade IVb-0; } \\
\text { grade V-2 }(0.08 \%)\end{array}$ \\
\hline $\begin{array}{l}\text { Özsoy M, Acar Ö, } \\
\text { Sarica K et al. }\end{array}$ & $87 \%$ & $\mathrm{~N} / \mathrm{S}$ & $\mathrm{N} / \mathrm{S}$ & $18(1.9 \%)$ & $1(0.1 \%)$ & $19(2.0 \%)$ & $17.20 \%$ & $\begin{array}{l}\text { Grade I-51 }(5.5 \%) \text {; grade II-21 } \\
(2.2 \%) \text {; grade IIIa-26 }(2.8 \%) ; \\
\text { grade IIIb-60 }(6.5 \%) \text {; grade } \\
\text { IV-1 }(0.1 \%)\end{array}$ \\
\hline $\begin{array}{l}\text { Moses RA, Ghali FM, } \\
\text { Pais VM Jr. et al. }\end{array}$ & $\mathrm{N} / \mathrm{S}$ & $\mathrm{N} / \mathrm{S}$ & $\mathrm{N} / \mathrm{S}$ & $19(3.4 \%)$ & $\mathrm{N} / \mathrm{S}$ & $19(3.4 \%)$ & $47(8.50 \%)$ & $\mathrm{N} / \mathrm{S}$ \\
\hline $\begin{array}{l}\text { James P. Blackmur, } \\
\text { Neil U. Maitra, } \\
\text { Rajendar R. Marri et al. }\end{array}$ & $83.40 \%$ & $\mathrm{~N} / \mathrm{S}$ & $\mathrm{N} / \mathrm{S}$ & $\mathrm{N} / \mathrm{S}$ & $34(7.4 \%)$ & $34(7.4 \%)$ & & $\begin{array}{l}\text { Grade IV-33 (7.1\%); grade } \\
\quad \text { V-1 }(0.22 \%)\end{array}$ \\
\hline $\begin{array}{l}\text { Dessyn JF, Balssa L, } \\
\text { Chabannes E et al. }\end{array}$ & $68 \%$ & $\mathrm{~N} / \mathrm{S}$ & $\mathrm{N} / \mathrm{S}$ & $\mathrm{N} / \mathrm{S}$ & $1(0.2 \%)$ & $\mathrm{N} / \mathrm{S}$ & $55(11 \%)$ & \\
\hline
\end{tabular}


Table 2 (continued)

\begin{tabular}{|c|c|c|c|c|c|c|c|c|}
\hline & & & & & & & & $\begin{array}{l}\text { Grade I-16 }(3.2 \%) \text {; grade II-37 } \\
\quad(5.4 \%) \text {; grade III-0; grade } \\
\text { IV }-1(0.2 \%)\end{array}$ \\
\hline $\begin{array}{l}\text { Berardinelli F, De } \\
\text { Francesco P, Marchioni } \\
\text { M et al. }\end{array}$ & $70.7 \%$ & $18(4.4 \%)$ & $7(1.7 \%)$ & $3(0.7 \%)$ & $3(0.7 \%)$ & $31(7.7 \%)$ & $7.7 \%$ & $\begin{array}{l}\text { Grade I-18 }(4.4 \%) \text {; grade II-10 } \\
\quad(2.5 \%) ; \text { grade IIIa }-34(8.4 \%)\end{array}$ \\
\hline $\begin{array}{l}\text { Nevo A, Mano R, } \\
\text { Baniel J et al. }\end{array}$ & $\mathrm{N} / \mathrm{S}$ & $\mathrm{N} / \mathrm{S}$ & $\mathrm{N} / \mathrm{S}$ & $\mathrm{N} / \mathrm{S}$ & $36(2.9 \%)$ & $\mathrm{N} / \mathrm{S}$ & $36(2.9 \%)$ & Grade IV $-36(2.9 \%)$ \\
\hline $\begin{array}{l}\text { Somani BK, Giusti G, } \\
\text { Sun Y et al. }\end{array}$ & $85.8 \%$ & $204(1.72 \%)$ & $\mathrm{N} / \mathrm{S}$ & $113(0.95 \%)$ & $36(0.3 \%)$ & $353(3.0 \%)$ & $874(7.35 \%)$ & $\begin{array}{l}\text { Grade I-141 }(1.2 \%) \text {; grade } \\
\text { II-152 }(1.3 \%) ; \text { grade IIIa-31 } \\
(0.26 \%) ; \text { grade IIIb-14 }(0.12 \%) \text {; } \\
\text { grade IVa-11 }(0.09 \%) \text {; grade } \\
\text { IVb-1 }(0.008 \%) \text {; grade IV }-5 \\
(0.042 \%)\end{array}$ \\
\hline $\begin{array}{l}\text { Ghosh A, Oliver R, } \\
\text { Way C, White L, } \\
\text { Somani BK }\end{array}$ & $94.2 \%$ & $\mathrm{~N} / \mathrm{S}$ & $\mathrm{N} / \mathrm{S}$ & $4(0.7 \%)$ & $9(1.65 \%)$ & $13(2.4 \%)$ & $22(4 \%)$ & $\begin{array}{l}\text { Grade I-8 }(1.5 \%) \text {; grade II }-12 \\
\quad(2.2 \%) ; \text { grade III-1 }(0.18 \%) ; \\
\text { grade IV }-0.18 \%\end{array}$ \\
\hline $\begin{array}{l}\text { Stauffer CE, Snyder E, } \\
\text { Ngo TC et al. }\end{array}$ & $\mathrm{N} / \mathrm{S}$ & $\mathrm{N} / \mathrm{S}$ & $\mathrm{N} / \mathrm{S}$ & $10(2.1 \%)$ & $\mathrm{N} / \mathrm{S}$ & $10(2.1 \%)$ & $10(2.1 \%)$ & Clavien $\mathrm{I}-10(2.1 \%)$ \\
\hline $\begin{array}{l}\text { C Senocak, C Ozcan, } \\
\text { T Sahin et al. }\end{array}$ & $\mathrm{N} / \mathrm{S}$ & $14(2.8 \%)$ & $23(4.7 \%)$ & $\mathrm{N} / \mathrm{S}$ & $5(1.0 \%)$ & $42(8.5 \%)$ & $22.1 \%$ & $\mathrm{~N} / \mathrm{S}$ \\
\hline $\begin{array}{l}\text { Uchida Y, Takazawa R, } \\
\text { Kitayama S et al. }\end{array}$ & 84.4 & $42(8.9 \%)$ & $27(5.7 \%)$ & $\mathrm{N} / \mathrm{S}$ & 1 & $70(14.9 \%)$ & $70(14.9 \%)$ & $\begin{array}{l}\text { Grade I }-42(8.9 \%) \text {; grade II-27 } \\
\quad(5.7 \%) \text {; grade IV }-1(0.2 \%)\end{array}$ \\
\hline $\begin{array}{l}\text { Southern JB, Higgins } \\
\text { AM, Young AJ et al. }\end{array}$ & $\mathrm{N} / \mathrm{S}$ & $229(6.9 \%)$ & & $\mathrm{N} / \mathrm{S}$ & $\mathrm{N} / \mathrm{S}$ & $229(6.9 \%)$ & $229(6.9 \%)$ & Grade $\mathrm{I}-229(6.9 \%)$ \\
\hline
\end{tabular}

\section{Data Extraction and Analysis}

Data was extracted for journal title, author's details, year of publication, country of origin, patient demographics, stone characteristics, overall and infection-related complications. Where the infectious complications were reported separately, it was recorded as such. The severity of complications was also categorised according to the Clavien-Dindo classification system for grading complications [32]. Studies which described risk factors for postURS infection, prevention and management strategies for postURS infections were also recorded. All data was recorded using Microsoft Excel 2019 (version 16.28).

\section{Results}

A total of 2070 articles were initially identified, and 14 full-text English language articles were included in the final review which fit our inclusion criteria (Fig. 1) [13, 15, 18-28]. The total number of ureteroscopies included in these papers was 24,373, and the mean age was 51.2 years (range $42-61$ years), male:female ratio of 3:2 and a mean BMI of 26.9 (range 23.7-31.8) (Table 1). All patients' demographic and procedure details were explored as possible risk factors for post-ureteroscopy infections (Table 2). These were gender, stone size or total stone burden, stone location, ureteral access sheath use and mean operative time. Other risk factors included patient comorbidities, history of recurrent UTIs or positive urine culture, immunocompromised patients, longer procedural time, pre-operative stent dwell time, previous indwelling catheter or neurogenic bladder Table 3).
For the papers which mentioned the stone size and location, the mean stone size (stone length) was $10.5 \mathrm{~mm}$ (range 8$14.3 \mathrm{~mm})$. The stone location was reported in 9 papers of which $54 \%(n=13,148)$ were ureteric stones, $22 \%(n=$ $5373)$ were renal stones, $8.6 \%(n=2115)$ were in multiple locations and in $15.4 \%$, it was not reported. A ureteral access sheath use was used in $25.8 \%(n=6288)$ patients and ranged across studies from 206 to 2263 cases. The mean operating time was $52.7 \mathrm{~min}$ (range 40-62.4 $\mathrm{min}$ ). The stone-free rate across studies was $83 \%$ (range 68-84.4\%).

The total number of complications were noted in $7.9 \%(n=$ 1919), of which 3.9\% ( $n=972)$ were infectious complications and $4 \%(n=1147)$ were non-infectious complications. Of all the infectious complications, fever was reported in $66 \%(n=$ 642). Urosepsis was reported in 7 papers, and there were 126 patients with urosepsis which was $0.51 \%$ of the whole cohort and $6.5 \%$ of the total reported complications.

Of the complications, grade I complication was reported in $67.6 \%(n=1298)$, grade II complication in $14.3 \%(n=275)$, grade IIIa complication in 5\% $(n=98)$, grade IIIb complication in $4.2 \%(n=82)$, grade IV complication in $4.7 \%(n=91)$ and grade $\mathrm{V}$ complication in $0.15 \%(n=3)$ patients.

\section{Discussion}

Our systematic review for high-volume centres shows a postURS urosepsis rates of $0.51 \%$. Antibiotic prophylaxis was practiced in most of the included studies and offers to reduce this risk [12]. It seems that there are several pre-disposing factors which 
Table 3 Infectious complications from the studies including risk factors, modifiable strategies and proposed management of complications (as mentioned by authors)

\begin{tabular}{|c|c|c|c|}
\hline Author & Risk factors & Risk modification strategies & Details of complications management \\
\hline Pricop C. et al. & $\begin{array}{l}\text { - Absence of antibiotic prophylaxis } \\
\text { - Stone size } 0.9-1.2 \mathrm{~cm}\end{array}$ & - Antibiotic prophylaxis & $\mathrm{N} / \mathrm{S}$ \\
\hline Martov A. et al. & $\begin{array}{l}\text { - Female gender } \\
\text { - High ASA score } \\
\text { - Older age } \\
\text { - Long pre-operative hospital stay } \\
\text { - Deficient nutritional status } \\
\text { - History of recurrent UTIs } \\
\text { - Impaired immune response } \\
\text { - Bowel surgery } \\
\text { - Diabetes mellitus } \\
\text { - Smoking } \\
\text { - Urinary obstruction } \\
\text { - Lack of control of risk factors }\end{array}$ & $\begin{array}{l}\text { - Antibiotic prophylaxis for all } \\
\text { patients undergoing URS }\end{array}$ & $\mathrm{N} / \mathrm{S}$ \\
\hline Özsoy M. et al. & - Female gender & $\mathrm{N} / \mathrm{S}$ & $\mathrm{N} / \mathrm{S}$ \\
\hline Moses RA. et al. & $\begin{array}{l}\text { - Longer OR time } \\
\text { - Pre-operative stent }\end{array}$ & $\begin{array}{l}\text { - Understanding local resistance } \\
\text { patterns } \\
\text { - Antibiotic prophylaxis } \\
\text { - Choose broadened prophylaxis, } \\
\text { in pre-stented and longer operations }\end{array}$ & $\mathrm{N} / \mathrm{S}$ \\
\hline James P. et al. & - Positive pre-operative culture & $\mathrm{N} / \mathrm{S}$ & - 1 case ITU—death \\
\hline Dessyn JF. et al. & - Stone size and number & $\mathrm{N} / \mathrm{S}$ & $\mathrm{N} / \mathrm{S}$ \\
\hline Berardinelli F. et al. & $\begin{array}{l}\text { - Coronary heart disease } \\
\text { - Anticoagulant therapy } \\
\text { - CKD } \\
\text { - Alteration of lipid metabolism } \\
\text { - Presence of residual fragments } \\
\text { - Past surgery for renal stone }\end{array}$ & $\mathrm{N} / \mathrm{S}$ & $\begin{array}{l}\text { - Fever-antipyretics } \\
\text { - SIRS-Abx, IV fluids } \\
\text { - Sepsis-Abx, IV fluids, Inotropes } \\
\text { - Obstructive pyelonephritis_-DJ placement } \\
\text { - Hospital re-admission, } 1.2 \%\end{array}$ \\
\hline Nevo A. et al. & $\begin{array}{l}\text { - Female gender } \\
\text { - Pre-operative stent long indwelling time }\end{array}$ & $\mathrm{N} / \mathrm{S}$ & $\mathrm{N} / \mathrm{S}$ \\
\hline Somani BK. et al. & $\mathrm{N} / \mathrm{S}$ & $\mathrm{N} / \mathrm{S}$ & $\mathrm{N} / \mathrm{S}$ \\
\hline Ghosh A. et al. & $\begin{array}{l}\text { - Long hospital stay } \\
\text { - Older age } \\
\text { - Positive pre-operative culture } \\
\text { - Longer OR time }\end{array}$ & $\mathrm{N} / \mathrm{S}$ & $\begin{array}{l}\text { - Sepsis managed with IV antibiotics; } \\
\text { - } 1 \text { case - ITU for candidaemia }\end{array}$ \\
\hline Stauffer CE. et al. & $\begin{array}{l}\text { - Neurogenic bladder } \\
\text { - Indwelling catheter } \\
\text { - Bacterial colonization }\end{array}$ & $\mathrm{N} / \mathrm{S}$ & $\mathrm{N} / \mathrm{S}$ \\
\hline Senocak C. et al. & - Positive pre-operative MDR culture & $\mathrm{N} / \mathrm{S}$ & $\mathrm{N} / \mathrm{S}$ \\
\hline Uchida Y. et al. & $\begin{array}{l}\text { - Female gender } \\
\text { - Lower BMI } \\
\text { - Deficient nutritional status } \\
\text { - Previous obstructive pyelonephritis } \\
\text { - Positive pre-operative culture } \\
\text { - Struvite stones } \\
\text { - Pre-operative stent }\end{array}$ & $\mathrm{N} / \mathrm{S}$ & - 1 case-ITU with vasopressors \\
\hline Southern JB. et al. & $\begin{array}{l}\text { - Female gender } \\
\text { - Longer OR time } \\
\text { - Multiple comorbidities } \\
\text { - Positive pre-operative culture }\end{array}$ & - Pre-operative counselling & - Sepsis — ward-based management \\
\hline
\end{tabular}

increases this risk and includes positive pre-operative UTI or prior history of UTIs, patients with higher Charlson comorbidity index or elderly patients, female gender, presence and duration of indwelling ureteric stents, procedural time and patients with a neurogenic bladder and with high BMI [18-28]. Infectious complications vary from fever, urinary tract infection, pyelonephritis, systemic inflammatory response syndrome and urosepsis. Antibiotics should therefore be tailored to local resistance profiles which tend to reduce rates of infection and urosepsis [33]. Baboudjian et al. propose that limiting operative times and 
treating pre-operative UTI should lead towards reduced postoperative infection rates [29].

There is a substantial patient and economic cost associated with sepsis, which is $>\$ 24$ billion per year in the USA alone [34]. Urosepsis leads to morbidity and mortality and hence, prevention, early detection and management are paramount [14]. It is the leading cause of mortality for patients with KSD and is more common in patients with comorbidities, high stone burden, obesity, with spinal cord injury or neurogenic bladders. The CROES study revealed a mortality rate of $0.04 \%$ which confirms that although the mortality rate of URS is negligible, but, it is not zero, and all precautions must be taken for it [13]. Prevention strategies included the use of prophylactic antibiotics, aggressive treatment of preoperative UTIs, reducing operating duration, caution in elderly and patients with high stone burden [14].

Previous work by Traxer et al. showed that the use of ureteral access sheath (UAS) helps to reduce post-URS infectious complication [35]. However, the use of UAS was not helpful in reducing infectious complications in another study looking at treatment of large renal stones [36]. The presence of indwelling stents more than 1 month was associated with a higher risk of sepsis [20॰]. Hence, any pre-procedural ureteric stent must be kept as short as possible prior to offering a definitive ureteroscopy.

In patients with urosepsis due to obstructed ureteric stone, an immediate drainage via a nephrostomy or ureteric stent is needed, in addition to antibiotics and supportive care [37]. A delayed ureteroscopy and stone treatment in these cases lead to good clinical outcome [37].

Urosepsis-related mortality was found to be 2.5 times higher in patients with urinary obstruction and is largely due to urolithiasis [38]. Urgent decompression in obstructed calculus-related sepsis is warranted; otherwise, the mortality is doubled, and this drainage should be early (within $48 \mathrm{~h}$ ) to reduce the hospital stay $[39,40]$. Although there is no consensus on the time duration between emergency drainage and elective ureteroscopy, it is generally agreed that this should be as soon as the patient has recovered from the initial sepsis and is stable to undergo the ureteroscopy [37].

\section{Conclusion}

Infectious complications following ureteroscopy can be a source of morbidity and potential mortality. Although majority of these are minor, efforts must be taken to minimize them especially in high-risk patients. This includes use of prophylactic antibiotics, limiting stent dwell and procedural time, prompt identification and treatment of UTI and urosepsis, and careful planning in patients with large stone burden and multiple comorbidities.

\section{Compliance with Ethical Standards}

Conflict of Interest The authors declare no potential conflicts of interest.

Human and Animal Rights and Informed Consent This article is a systematic review of literature and hence, no direct patient involvement was recorded or analysed.

Open Access This article is licensed under a Creative Commons Attribution 4.0 International License, which permits use, sharing, adaptation, distribution and reproduction in any medium or format, as long as you give appropriate credit to the original author(s) and the source, provide a link to the Creative Commons licence, and indicate if changes were made. The images or other third party material in this article are included in the article's Creative Commons licence, unless indicated otherwise in a credit line to the material. If material is not included in the article's Creative Commons licence and your intended use is not permitted by statutory regulation or exceeds the permitted use, you will need to obtain permission directly from the copyright holder. To view a copy of this licence, visit http://creativecommons.org/licenses/by/4.0/.

\section{References}

Papers of particular interest, published recently, have been highlighted as:

- Of importance

1. Romero V, Akpinar H, Assimos DG. Kidney stones: a global picture of prevalence, incidence, and associated risk factors. Rev Urol 2010.

2. Rukin NJ, Siddiqui ZA, Chedgy ECP, Somani BK. Trends in upper tract stone disease in England: evidence from the hospital episodes statistics database. Urol Int. 2017. https://doi.org/10.1159/ 000449510.

3. Geraghty RM, Proietti S, Traxer O, Archer M, Somani BK. Worldwide impact of warmer seasons on the incidence of renal colic and kidney stone disease: evidence from a systematic review of literature. J Endourol. 2017. https://doi.org/10.1089/end.2017. 0123. A comprehensive review showing the clear association between warm weather and incidence of kidney stone disease.

4. Assimos D, Krambeck A, Miller NL, et al. Surgical management of stones: American Urological Association/Endourological Society guideline, PART I. J Urol. 2016. https://doi.org/10.1016/j.juro. 2016.05.090.

5. Turk, Knoll, Petrik, Sarica, Skolarikos, Straub S, Turk C, Petrik A, et al. EAU Guidelines on urolithiasis. Eur Assoc Urol. 2018. doi: https://doi.org/10.1002/wrcr.20090.

6. Anagnostou T, Tolley D. Management of ureteric stones. Eur Urol. 2004. https://doi.org/10.1016/j.eururo.2003.10.018.

7. Pietropaolo A, Proietti S, Geraghty R, et al. Trends of 'urolithiasis: interventions, simulation, and laser technology' over the last 16 years (2000-2015) as published in the literature (PubMed): a systematic review from European section of Uro-technology (ESUT). World J Urol. 2017. https://doi.org/10.1007/s00345-017-2055-z. A review paper showing the publication trend related to different urological interventions.

8. Geraghty RM, Jones P, Somani BK. Worldwide trends of urinary stone disease treatment over the last two decades: a systematic review. J Endourol. 2017. https://doi.org/10.1089/end.2016.0895. 
9. Preminger GM, Tiselius HG, Assimos DG, et al. 2007 guideline for the management of ureteral calculi. J Urol. 2007. https://doi.org/10. 1016/j.juro.2007.09.107.

10. Geavlete P, Georgescu D, Niță G, Mirciulescu V, Cauni V. Complications of 2735 retrograde semirigid ureteroscopy procedures: a single-center experience. J Endourol. 2006. https://doi. org/10.1089/end.2006.20.179.

11. Perez Castro E, Osther PJS, Jinga V, et al. Differences in ureteroscopic stone treatment and outcomes for distal, mid-, proximal, or multiple ureteral locations: the clinical research office of the endourological society ureteroscopy global study. Eur Urol. 2014. https://doi.org/10.1016/j.eururo.2014.01.011.

12. Grabe M. Controversies in antibiotic prophylaxis in urology. In: Int J Antimicrob Agents. ; 2004. doi:https://doi.org/10.1016/j. ijantimicag.2003.09.005.

13. Somani BK, Giusti G, Sun Y, et al. Complications associated with ureterorenoscopy (URS) related to treatment of urolithiasis: the Clinical Research Office of Endourological Society URS Global study. World J Urol. 2017. https://doi.org/10.1007/s00345-0161909-0. CROES data showing the URS complications for more than 11,000 patients. This was a multicentic study across all continents.

14. Whitehurst L, Jones P, Somani BK. Mortality from kidney stone disease (KSD) as reported in the literature over the last two decades: a systematic review. World J Urol. 2019;37:759-76. https://doi.org/ 10.1007/s00345-018-2424-2.

15. Ghosh A, Oliver R, Way C, White L, Somani BK. Results of daycase ureterorenoscopy (DC-URS) for stone disease: prospective outcomes over 4.5 years. World J Urol. 2017. https://doi.org/10. 1007/s00345-017-2061-1.

16. Somani BK, Dellis A, Liatsikos E, Skolarikos A. Review on diagnosis and management of urolithiasis in pregnancy: an ESUT practical guide for urologists. World J Urol. 2017;35:1637-49. https:// doi.org/10.1007/s00345-017-2037-1.

17. Somani BK, Moseley H, Eljamel MS, Nabi G, Kata SG. Photodynamic diagnosis (PDD) for upper urinary tract transitional cell carcinoma (UT-TCC): evolution of a new technique. Photodiagn Photodyn Ther. 2010. https://doi.org/10.1016/j.pdpdt. 2009.12.005.

18. Pricop C, Dorobăț C, Puia D, Orsolya M. Antibiotic prophylaxis in retrograde ureteroscopy: what strategy should we adopt? GERMS. 2013. https://doi.org/10.11599/germs.2013.1045.

19. Özsoy M, Acar, Sarica K, et al. Impact of gender on success and complication rates after ureteroscopy. World J Urol. 2015. https:// doi.org/10.1007/s00345-014-1435-x.

20. Nevo A, Mano R, Baniel J, Lifshitz DA. Ureteric stent dwelling time: a risk factor for post-ureteroscopy sepsis. BJU Int. 2017. https://doi.org/10.1111/bju.13796. An important paper showing that longer stent dwell time was associated with post-URS sepsis.

21. Blackmur JP, Maitra NU, Marri RR, Housami F, Malki M, Mcilhenny C. Analysis of factors' association with risk of postoperative urosepsis in patients undergoing ureteroscopy for treatment of stone disease. In: J Endourol. 2016. doi:https://doi.org/10.1089/ end.2016.0300.

22. Stauffer CE, Snyder E, Ngo TC, Elliott CS. Is neurogenic bladder a risk factor for febrile urinary tract infection after ureteroscopy and, if so, why? Urology. 2018. https://doi.org/10.1016/j.urology.2017. 10.006 .

23. Uchida Y, Takazawa R, Kitayama S, Tsujii T. Predictive risk factors for systemic inflammatory response syndrome following ureteroscopic laser lithotripsy. Urolithiasis. 2018;46:375-81. https://doi.org/10.1007/s00240-017-1000-3.

24. Martov A, Gravas S, Etemadian M, et al. Postoperative infection rates in patients with a negative baseline urine culture undergoing ureteroscopic stone removal: a matched case-control analysis on antibiotic prophylaxis from the CROES URS global study. J Endourol. 2015. https://doi.org/10.1089/end.2014.0470.

25. Moses RA, Ghali FM, Pais VM, Hyams ES. Unplanned hospital return for infection following ureteroscopy — can we identify modifiable risk factors? J Urol. 2016. https://doi.org/10.1016/j.juro.2015.09.074.

26. Dessyn JF, Balssa L, Chabannes E, et al. Flexible ureterorenoscopy for renal and proximal ureteral stone in patients with previous ureteral stenting: impact on stone-free rate and morbidity. J Endourol. 2016. https://doi.org/10.1089/end.2016.0045.

27. Southern JB, Higgins AM, Young AJ, et al. Risk factors for postoperative fever and systemic inflammatory response syndrome after ureteroscopy for stone disease. J Endourol. 2019. https://doi.org/10. 1089/end.2018.0789.

28. Senocak C, Ozcan C, Sahin T, et al. Risk factors of infectious complications after flexible uretero-renoscopy with laser lithotripsy. Urol J. 2018. https://doi.org/10.22037/uj.v0i0.3967.

29. Baboudjian M, Gondran-Tellier B, Abdallah R, Sichez PC, Akiki A, Gaillet S, et al. Predictive risk factors of urinary tract infection following flexible ureteroscopy despite preoperative precautions to avoid infectious complications. World J Urol. 2019:1-7. https://doi. org/10.1007/s00345-019-02891-8.

30. Higgins JP, Green S. Cochrane handbook for systematic reviews of interventions: cochrane book series.; 2008. doi:https://doi.org/10. 1002/9780470712184

31. Moher D, Liberati A, Tetzlaff J, Altman DG. Preferred reporting items for systematic reviews and meta-analyses: the PRISMA statement. J Clin Epidemiol. 2009. https://doi.org/10.1016/j.jclinepi. 2009.06.005.

32. Dindo D, Demartines N, Clavien PA. Classification of surgical complications: a new proposal with evaluation in a cohort of 6336 patients and results of a survey. Ann Surg. 2004. https://doi. org/10.1097/01.sla.0000133083.54934.ae.

33. Zisman A, Badaan S, Kastin A, et al. Tailoring antibiotic prophylaxis for ureteroscopic procedures based on local resistance profiles may Lead to reduced rates of infections and urosepsis. Urol Int. 2019;19:1-7. https://doi.org/10.1159/000503905.

34. Lagu T, Rothberg MB, Shieh MS, et al. Hospitalizations, costs, and outcomes of severe sepsis in the United States 2003 to 2007. Crit Care Med. 2012;40(3):754-61.

35. Traxer O, Wendt-Nordahl G, Sodha H, Rassweiler J, Meretyk S, Tefekli A, et al. Differences in renal stone treatment and outcomes for patients treated either with or without the support of a ureteral access sheath: the Clinical Research Office of the Endourological Society Ureteroscopy Global Study. World J Urol. 2015;33(12):2137-44.

36. Geraghty RM, Ishii H, Somani BK. Outcomes of flexible ureteroscopy and laser fragmentation for treatment of large renal stones with and without the use of ureteral access sheaths: results from a university hospital with a review of literature. Scand J Urol. 2016;50(3):216-9.

37. Pietropaolo A, Hendry J, Kyriakides R, et al. Outcomes of elective ureteroscopy for ureteric stones in patients with prior urosepsis and emergency drainage: prospective study over $5 \mathrm{yr}$ from a Tertiary Endourology Centre. Eur Urol Focus. 2018. https://doi.org/10. 1016/j.euf.2018.09.001

38. Reyner $\mathrm{K}$, Heffner AC, Karvetski $\mathrm{CH}$, et al. Urinary obstruction is an important complicating factor in patients with septic shock due to urinary infection. Am J Emerg Med. 2016;34:694-6.

39. Borofsky MS, Walter D, Shah O, et al. Surgical decompression is associated with decreased mortality in patients with sepsis and ureteral calculi. J Urol. 2013;189:946-51.

40. Nishiguchi S, Branch J, Yu S, et al. Effectiveness of early ureteric stenting for urosepsis associated with urinary tract calculi. Intern Med. 2014;53:2205-10.

Publisher's Note Springer Nature remains neutral with regard to jurisdictional claims in published maps and institutional affiliations. 